\title{
Accelerated ripening of Caciocavallo Pugliese cheese with attenuated adjuncts of selected nonstarter lactobacilli
}

\author{
R. Di Cagno, I. De Pasquale, M. De Angelis, and M. Gobbetti ${ }^{1}$ \\ Department of Biologia e Chimica Agro-Forestale ed Ambientale, University of Bari Aldo Moro, 70126 Bari, Italy
}

\begin{abstract}
The nonstarter lactic acid bacteria Lactobacillus plantarum CC3M8, Lactobacillus paracasei CC3M35, and Lactobacillus casei LC01, previously isolated from aged Caciocavallo Pugliese cheese or used in cheesemaking, were used as adjunct cultures (AC) or attenuated (by sonication treatment) adjunct cultures (AAC) for the manufacture of Caciocavallo Pugliese cheese on an industrial scale. Preliminary studies on the kinetics of growth and acidification and activities of several enzymes of AAC were characterized in vitro. As shown by the fluorescence determination of live versus dead or damaged cells and other phenotype features, attenuation resulted in a portion of the cells being damaged and a portion of the cells being capable of growing with time. Compared with the control cheese (without adjunct cultures) and the cheese with AAC, the addition of $\mathrm{AC}$ resulted in a lower $\mathrm{pH}$ after manufacture, which altered the gross composition of the cheese. As shown by plate count and confirmed by random amplification of polymorphic DNA-PCR, the 3 species of nonstarter lactobacilli persisted during ripening but the number of cultivable cells varied between AC and AAC. Slight differences were found between cheeses regarding primary proteolysis. The major differences between cheeses were the accumulation of free amino acids and the activity levels of several enzymes, which were highest in the Caciocavallo Pugliese cheeses made with the addition of AAC. As shown by triangle test, the sensory properties of the cheese made with AAC at $45 \mathrm{~d}$ did not differ from those of the control Caciocavallo Pugliese cheese at $60 \mathrm{~d}$ of ripening. In contrast, the cheese made with $\mathrm{AC}$ at $45 \mathrm{~d}$ differed from both the Caciocavallo Pugliese cheese without adjuncts and the cheese made with AAC. Attenuated adjunct cultures are suitable for accelerating the ripening of Caciocavallo Pugliese cheese without modifying the main features of the traditional cheese.
\end{abstract}

Received December 21, 2011.

Accepted May 10, 2012.

${ }^{1}$ Corresponding author: gobbetti@agr.uniba.it
Key words: adjunct culture, attenuation by sonication, Caciocavallo cheese

\section{INTRODUCTION}

Nonstarter lactic acid bacteria (NSLAB), mainly of the genus Lactobacillus, predominate during ripening of several varieties of cheeses (Crow et al., 2001). For some cheese varieties, NSLAB represent the main biological agents resulting in the typical sensory properties (De Angelis et al., 2001). Generally, the NSLAB remain uncontrolled in industrial cheese making because offflavors, formation of biogenic amines, and blowing may occur if the dominant strains are altered (Crow et al., 2001). Although the control of the NSLAB biota could be pursued through the use of adjunct cultures, this procedure seems to be outdated due to several risks such as excessive acidification during manufacture and the variable effects on texture and sensory properties of the cheeses.

Over the last decade (Madkor et al., 2000; Upadhyay et al., 2007), adjuncts of mesophilic nonstarter lactobacilli have also been used as attenuated cultures. Several methods have been used to achieve attenuation, including heat treatment, freezing and thawing, freezeor spray-drying, lysozyme treatment, use of solvents, and high-pressure treatment (Klein and Lortal, 1999; Upadhyay et al., 2007). Recently, sonication has been proposed for the attenuation of adjuncts of mesophilic nonstarter lactobacilli used in making Italian Caciottatype cheese (Di Cagno et al., 2011). Sonication appeared to be a novel and efficient method to attenuate adjunct cultures, because it was simple, rapid, and reproducible and did not alter the activity of intracellular enzymes (Di Cagno et al., 2011). Overall, attenuated cultures of mesophilic nonstarter lactobacilli should not have the capacity to transport, phosphorylate, and hydrolyze lactose during cheese manufacture, but they must contain enzymes that influence cheese quality during ripening. Only a few studies (Upadhyay et al., 2007) have demonstrated, in part, how attenuation interferes with cell viability and how attenuated cultures may recover capacities of growth and acidification in vitro 
and during cheesemaking. The ultimate goal of using selected and attenuated strains of NSLAB is to accelerate and improve flavor and texture development during cheese ripening.

None of the previous studies has considered the use of attenuated adjuncts of selected nonstarter lactobacilli during the manufacture of semi-hard pasta filata cheeses. Stretching of the curd in hot water is undoubtedly a selective technology parameter, which may influence the performance of attenuated adjunct cultures. Caciocavallo, a typical pasta filata cheese, is manufactured in 3 different regions: the Balkans, Russia, and Italy. Different varieties of Caciocavallo cheese are manufactured in southern Italy, including Caciocavallo Silano, Molisano, Pugliese, and Corleonese. Caciocavallo Pugliese has very wide market popularity — approximately 9,234 $\mathrm{t}$ are manufactured per year (www.istat.it). The cheese is made from raw cow milk, using natural whey or freeze-dried primary starters, and a temperature $>70^{\circ} \mathrm{C}$ is used during plasticization of the curd, which results in the formation of paracasein fibers of relatively high tensile strength that impart stringiness to the cheese (Gobbetti et al., 2002). Caciocavallo Pugliese cheese may be sold after just 2 wk of ripening or, more commonly, after 2 to 4 mo. The cheese typically has an oval or flask-like shape due to the way the curd is handled during stretching. After manufacture, the end of the body curd is tied with a cord, which is attached to a long, robust stick throughout the ripening period. The ripened cheese weighs 1 to $2.5 \mathrm{~kg}$, the rind is pale yellow, and the interior is compact with small eyes. Defects of texture and flavor may sometimes appear due to uncontrolled fermentation or enzyme activities and because of the use of raw cow milk.

This study describes the in vitro kinetics of growth and acidification of attenuated (by sonication treatment) adjuncts of 3 selected nonstarter lactobacilli used to accelerate the ripening of Caciocavallo Pugliese cheese. Traditional cheesemaking and the use of nonattenuated selected lactobacilli strains were compared with respect to compositional, microbiological, biochemical, and sensory characteristics.

\section{MATERIALS AND METHODS}

\section{Mesophilic Nonstarter Lactobacilli}

Lactobacillus plantarum CC3M8 and Lactobacillus paracasei CC3M35, which were previously isolated from aged Caciocavallo cheeses, and Lactobacillus casei LC01, belonging to the Culture Collection of the Department of Biologia e Chimica Agro-Forestale ed Ambientale (Bari University, Bari, Italy) and previously used in cheese making (Di Cagno et al., 2011), were identified by partial sequencing of the $16 \mathrm{~S}$ rRNA. The 3 strains were selected based on activities of aminopeptidase type $\mathrm{N}$, proline iminopeptidase, endopeptidase type $\mathrm{O}$, glutamate dehydrogenase, and cystathionine lyase (Di Cagno et al., 2011) and used as adjunct attenuated cultures.

\section{Adjunct and Attenuated Adjunct Cultures}

After overnight cultivation in in de Man, Rogosa, and Sharpe (MRS) broth (Oxoid, Basingstoke, UK), selected mesophilic nonstarter lactobacilli used as adjunct cultures (AC) were harvested by centrifugation $\left(10,000 \times g, 10 \mathrm{~min}\right.$ at $\left.4^{\circ} \mathrm{C}\right)$, washed twice with sterile $50 \mathrm{~m} M$ potassium phosphate buffer, $\mathrm{pH} 7.0$, and resuspended in sterile distilled water at the cell count of $\sim 9.0 \log _{10} \mathrm{cfu} / \mathrm{mL}$. This cell suspension was used to inoculate sterile skim milk (Oxoid). To obtain attenuated adjunct cultures (AAC), the same volume of harvested cells from MRS broth was resuspended in distilled water to the same cell count $(\sim 9.0 \pm 0.2$ $\log _{10} \mathrm{cfu} / \mathrm{mL}$ ), and the cell suspension was subjected to sonication in an ice bath. Sonication was carried out by using a Vibra-Cell sonicator (Sonic and Materials Inc., Danbury, CT) with a microtip setting (sonic power 375 $\mathrm{W}$; output control 5) for $45 \mathrm{~min}$ (3 cycles, $15 \mathrm{~min} /$ cycle, 15-min interval between cycles). As estimated by plate count, sonication decreased the cell number to $\sim 5.1 \pm 0.1 \log _{10} \mathrm{cfu} / \mathrm{mL}$. Then, AC (final cell count of $\sim 7.0 \pm 0.3 \log _{10} \mathrm{cfu} / \mathrm{mL}$ ) and AAC (cell count, before sonication treatment, of $\sim 9.0 \pm 0.2 \log _{10} \mathrm{cfu} / \mathrm{mL}$, which corresponded to $\sim 5.1 \pm 0.1 \log _{10} \mathrm{cfu} / \mathrm{mL}$ of cultivable cells) were individually incubated in sterile skim milk $\left(30^{\circ} \mathrm{C}\right.$ for $\left.80 \mathrm{~h}\right)$ or MRS broth $\left(30^{\circ} \mathrm{C}\right.$ for $\left.24 \mathrm{~h}\right)$. Kinetics of growth and acidification were determined. Growth was monitored by plating on MRS agar at $30^{\circ} \mathrm{C}$ for 48 h. Acidification was directly determined by a Foodtrode electrode (Hamilton, Bonaduz, Switzerland). Growth and acidification data were modeled according to the Gompertz equation, as modified by Zwietering et al. (1990):

$y=k+\mathrm{A} \exp \left\{-\exp \left[\left(\mu_{\max }\right.\right.\right.$ or $\left.\left.\left.\mathrm{V}_{\max } \mathrm{e} / \mathrm{A}\right)(\lambda-t)+1\right]\right\}$,

where $y$ is growth expressed as $\log _{10} \mathrm{cfu} / \mathrm{mL}$ per hour or acidification extent expressed as $\mathrm{dpH} / \mathrm{dt}$ (units of $\mathrm{pH} / \mathrm{h}$ ) at the time $t ; k$ is the initial level of the dependent variable to be modeled $\left(\log _{10} \mathrm{cfu} / \mathrm{mL}\right.$ or $\mathrm{pH}$ units); $\mathrm{A}$ is the difference in cell count or $\mathrm{pH}$ (units) between inoculation and the stationary phase; $\mu_{\max }$ or $\mathrm{V}_{\max }$ is the maximum growth rate expressed as $\Delta \log _{10}$ $\mathrm{cfu} / \mathrm{mL}$ per hour or the maximum acidification rate 
expressed as $\mathrm{dpH} / \mathrm{h}$, respectively; $\lambda$ is the length of the latency phase expressed in hours; and $t$ is the time. The experimental data were modeled through the nonlinear regression procedure of the statistics package Statistica for Windows (Statsoft, Tulsa, OK).

\section{Determination of Cell Membrane Integrity}

Cell membrane integrity of AAC was estimated using the LIVE/DEAD BacLight Bacterial Viability Kit (Molecular Probes Inc., Cambridge Bioscience, Cambridge, UK), according to the manufacturer's instruction. The analysis determines the structural integrity of the bacterial membrane using the green-fluorescing dye SYTO 9 and the red-fluorescing propidium iodide; SYTO 9 labels all cells, whereas propidium iodide penetrates only cells with a damaged membrane, causing a decrease in SYTO 9 fluorescence when both dyes are present. Stained bacterial suspensions were observed using a Leica LDMC (Leica Microsystems SpA, Milano, Italy) with a $60 \times$ objective. Images were analyzed and cell numbers were quantified from the images using Image-Pro Plus image analysis software (Media Cybernetics Inc., Silver Spring, MD; Biggerstaff et al., 2006).

\section{Enzyme Activities}

Enzyme activities were determined during incubation of $\mathrm{AC}$ and $\mathrm{AAC}$ in sterile skim milk and during ripening of Caciocavallo Pugliese cheese. In both cases, enzyme activities were determined in the water-soluble extracts of milk or cheese prepared according to the method of Kuchroo and Fox (1982), with further modifications (Di Cagno et al., 2006). Aminopeptidase (EC 3.4.11.11) type $\mathrm{N}$ activity on Leu- $p$-nitroanilide ( $p$-NA), proline iminopeptidase (EC 3.4.11.9) activity on Pro- $p$-NA, and endopeptidase type O (EC 3.4.23) activity on Z-Gly-Pro-NH-trifluoromethyl-coumarin were determined as described by Gobbetti et al. (1999). An arbitrary unit of enzymatic activity was defined as the amount of enzyme that caused an increase in absorbance at $410 \mathrm{~nm}$ per minute of 1 (aminopeptidase type N), 0.1 (proline iminopeptidase), and 0.1 (endopeptidase type $\mathrm{O}$ ) at $37^{\circ} \mathrm{C}$ and $\mathrm{pH}$ 7.0. Glutamate dehydrogenase (EC 1.4.1.2) activity was determined on glutamate by measuring the glutamate-dependent reduction of NADP or NAD at $340 \mathrm{~nm}$, as described by De Angelis et al. (2010). An arbitrary unit of enzymatic activity was defined as the amount of enzyme that gave an increase of absorbance of 0.1 per minute at $37^{\circ} \mathrm{C}$ and $\mathrm{pH}$ 7.0. Cystathionine lyase (EC 4.4.1.1) activity was determined by measuring the amount of ketoacids, ammonia, and free thiols released from cystathionine, as described by De Angelis et al. (2002). An arbitrary unit of enzymatic activity was defined as the amount of enzyme that caused an increase of absorbance (412 nm) of 1 per minute at $37^{\circ} \mathrm{C}$ and $\mathrm{pH}$ 7.0.

\section{Manufacture of Caciocavallo Pugliese Cheese}

The cow milk used in cheesemaking had the following characteristics: lactose $4.9 \%$, protein $3.3 \%$, fat $3.6 \%$, and $\mathrm{pH}$ 6.6. Daily, the same milk was used for the manufacture of the 3 types (control cheese without addition, cheese with adjunct cultures of AC or AAC) of cheese at an industrial plant (Ignalat, Noci Bari, Italy; vat of $\sim 200 \mathrm{~L}$ ). Cheesemaking was carried out on 3 consecutive days (total of 3 batches for each type of cheese) using cheese milk from daily milking. When used for cheesemaking (AC or AAC), the 3 mesophilic nonstarter lactobacilli were added as a mixture. Raw cow milk was heated at $37^{\circ} \mathrm{C}$ and inoculated with (1) freeze-dried (Sacco, Cadorago, Como, Italy) primary starter Streptococcus thermophilus (initial cell count of $\sim 7.0 \pm 0.2 \log _{10} \mathrm{cfu} / \mathrm{mL}$ of milk; control cheese, CC), (2) primary starter and AC (initial cell count of each species of $\sim 7.2 \pm 0.2 \log _{10} \mathrm{cfu} / \mathrm{mL}$ of milk), or (3) primary starter and AAC (cell count of each species, before sonication treatment, of $\sim 9.1 \pm 0.2 \log _{10} \mathrm{cfu} /$ $\mathrm{mL}$, which corresponded to $\sim 5.2 \pm 0.1 \log _{10} \mathrm{cfu} / \mathrm{mL}$ of cultivable cells in the milk). After $30 \mathrm{~min}$ at $37^{\circ} \mathrm{C}$, liquid calf rennet $(35 \mathrm{~mL} / 100 \mathrm{~L})$ was added and coagulation took place within $30 \mathrm{~min}$. The coagulum was first cut coarsely by hand, held under whey at $37^{\circ} \mathrm{C}$ for $2 \mathrm{~h}$, and then reduced mechanically to particles of 1.5 to 2 $\mathrm{cm}$. When the curd reached a $\mathrm{pH}$ of $5.3(\sim 1 \mathrm{~h})$, it was stretched in hot water $\left(80^{\circ} \mathrm{C}\right)$. Cheeses were salted in brine $(28 \%$, wt/vol, $\mathrm{NaCl})$ for $8 \mathrm{~h}$ and ripened at $12^{\circ} \mathrm{C}$ for 2 mo. The weight of the cheeses was approximately $1 \mathrm{~kg}$.

\section{Microbiological Analyses}

Samples (20 g) of Caciocavallo cheese were diluted in $180 \mathrm{~mL}$ of sodium citrate $(2 \%$, wt/vol $)$ solution and homogenized with a Stomacher Lab-Blender 400 (PBI International, Milan, Italy). Serial dilutions were made in quarter-strength Ringer's solution and plated on M17 or MRS agar (Oxoid) to enumerate presumptive thermophilic streptococci $\left(42^{\circ} \mathrm{C}\right.$ for $\left.48 \mathrm{~h}\right)$ or mesophilic lactic acid bacteria $\left(30^{\circ} \mathrm{C}\right.$ for $48-72 \mathrm{~h}$, under anaerobiosis). Colonies were collected from the plates (MRS agar incubated at $30^{\circ} \mathrm{C}$ for $48-72 \mathrm{~h}$, under anaerobiosis) of the highest dilutions of each cheese to detect the mesophilic nonstarter lactobacilli used as adjuncts. Grampositive, catalase-negative, nonmotile rod isolates were cultivated in MRS broth (Oxoid) at $30^{\circ} \mathrm{C}$ for $24 \mathrm{~h}$ and restreaked into MRS agar. 


\section{Random Amplified Polymorphic DNA-PCR Analysis}

Genomic DNA was extracted as described by de Los Reyes-Gavilán et al. (1992) from $2 \mathrm{~mL}$ of overnight culture grown in MRS at $30^{\circ} \mathrm{C}$. Two primers (Invitrogen Life Technologies, Milan, Italy), with arbitrarily chosen sequences (P4, 5'-CCGCAGCGTT-3' and M13, 5'-GAGGGTGGCGGTTCT-3'; De Angelis et al., 2001; Rossetti and Giraffa, 2005) were used singly in 2 series of amplification. The reaction mixture contained 200 $\mu \mathrm{mol} / \mathrm{L}$ of each dNTP, 1 to $2 \mu \mathrm{mol} / \mathrm{L}$ of primer, 1.5 to $3 \mu \mathrm{mol} / \mathrm{L}$ of $\mathrm{MgCl}_{2}, 1.25 \mathrm{U}$ Taq DNA polymerase (Invitrogen), $2.5 \mu \mathrm{L}$ of PCR buffer, $25 \mathrm{ng}$ of DNA, and sterile double distilled water to $25 \mu \mathrm{L}$. For amplifications with primer $\mathrm{P} 4$, the PCR program comprised 45 cycles of denaturation for $1 \mathrm{~min}$ at $94^{\circ} \mathrm{C}$, annealing for $1 \mathrm{~min}$ at $35^{\circ} \mathrm{C}$, and elongation for $2 \mathrm{~min}$ at $72^{\circ} \mathrm{C}$; the cycles were preceded by denaturation at $94^{\circ} \mathrm{C}$ for 4 min and followed by elongation at $72^{\circ} \mathrm{C}$ for 5 min. For primer M13, amplification reactions were carried out according to the protocol described by Giraffa et al. (2000): one cycle at $94^{\circ} \mathrm{C}$ for $60 \mathrm{~s}$ (denaturing), $42^{\circ} \mathrm{C}$ for $20 \mathrm{~s}$ (annealing), and $72^{\circ} \mathrm{C}$ for 2 min (elongation). The PCR products were separated by electrophoresis $(2 \mathrm{~h}$ at $130 \mathrm{~V}$ ) on $1.5 \%$ (wt/vol) agarose gel (Invitrogen), and the DNA was detected by UV transillumination after staining with ethidium bromide $(0.5 \mu \mathrm{g} / \mathrm{mL})$. The molecular weight of the amplified DNA fragments was estimated by comparison with the $1 \mathrm{~kb}$ Plus DNA Ladder (Invitrogen) ranging from 100 to 12,000 bp.

Random amplification of polymorphic DNA (RAPD)-PCR analyses were carried out for typing isolates during ripening of Caciocavallo Pugliese cheese to detect AAC. The reproducibility of RAPD fingerprints was assessed by comparing the PCR products obtained from 3 separate cultures of the same strain. After typing, isolates were identified by $16 \mathrm{~S}$ rRNA gene sequence analysis (De Angelis et al., 2006).

\section{Compositional and Biochemical Analyses}

Samples of cheese were analyzed for protein (macroKjeldahl; IDF, 1964), fat (Gerber method; IIRS, 1955), moisture (oven drying at $102^{\circ} \mathrm{C}$; IDF, 1982), and salt (Fox, 1963).

The $\mathrm{pH}$ 4.6-insoluble and $\mathrm{pH}$ 4.6-soluble nitrogen fractions of the cheeses were analyzed by urea-PAGE and reverse phase-HPLC as described by Di Cagno et al. (2003) and Gobbetti et al. (2002), respectively. Total and individual free amino acids (FAA) from the watersoluble extracts of cheeses were determined by the Biochrom 30 series Amino Acid Analyzer (Biochrom Ltd., Cambridge Science Park, UK; Di Cagno et al., 2007).

\section{Sensory Analysis}

Sensory analysis was carried out on Caciocavallo Pugliese cheeses made without addition (CC) after $60 \mathrm{~d}$ of ripening and with $\mathrm{AAC}$ or $\mathrm{AC}$ after $45 \mathrm{~d}$ of ripening. The triangle test was applied (ISO, 2004), choosing $\alpha$ $=0.05, \beta=0.05, \mathrm{Pd}=40 \%$ (where $\alpha$ is the probability of concluding that a perceptible difference exists when one does not, $\beta$ is the probability of concluding that no perceptible difference exists when one does, and $\mathrm{Pd}$ is the proportion of assessments in which a perceptible difference is detected between the 2 products), and 42 assessors to attempt the sensory evaluation. Assessors were chosen from students, researchers, and employees of the Department of Biologia e Chimica Agro-Forestale ed Ambientale (Bari, Italy), with an equal distribution of men and women and ranging in age between 21 and 45 yr. Six different combinations for each triangle test (CC-CC-AAC, CC-AAC-CC, AAC-CC-CC, AACAAC-CC, AAC-CC-AAC, CC-AAC-AAC; CC-CC-AC, CC-AC-CC, AC-CC-CC, AC-AC-CC, AC-CC-AC, CC$\mathrm{AC}-\mathrm{AC}$; and AC-AC-AAC, AC-AAC-AC, AAC-AC$\mathrm{AC}, \mathrm{AAC}-\mathrm{AAC}-\mathrm{AC}, \mathrm{AAC}-\mathrm{AC}-\mathrm{AAC}$ AC-AAC-AAC) were considered and distributed in randomized order to the assessors. The forced-choice procedure was applied. For the sessions, cheese samples were randomly coded and served, in aliquots of $20 \mathrm{~g}$ together with still water, to assessors placed in separate rooms for unbiased evaluation.

\section{Statistical Analysis}

All cheese analyses were carried out twice for each of the 3 batches (total 6 analyses for each type of cheese). Data were subjected to one-way ANOVA (SAS Institute, 1985); pair-comparison of treatment means was achieved by Tukey's procedure at $P<0.05$, using the statistical software Statistica for Windows (Statistica $6.0,1998)$. For sensory analysis, the statistical tables annexed to ISO (2004) and ISO (2008) were used.

\section{RESULTS AND DISCUSSION}

\section{In Vitro Kinetics of Growth and Acidification}

Lactobacillus casei LC01, Lactobacillus plantarum CC3M8, and Lactobacillus paracasei CC3M35 were previously isolated from aged Caciocavallo Pugliese cheese or used in cheesemaking (Di Cagno et al., 2011) and were selected based on various enzyme activities (see Materials and Methods).

Strains were singly subjected to attenuation by sonication treatment, and the kinetics of growth and acidi- 
fication were assayed on sterile skim milk $\left(30^{\circ} \mathrm{C}\right.$ for 80 $\mathrm{h})$ and MRS broth $\left(30^{\circ} \mathrm{C}\right.$ for $\left.24 \mathrm{~h}\right)$. Untreated AC grew into sterile milk from $\sim 7.0 \log _{10} \mathrm{cfu} / \mathrm{mL}$ to an average value of $9.5 \pm 0.2 \log _{10} \mathrm{cfu} / \mathrm{mL}$. Strains differed in the latency phase of growth, which may reflect the different capacity to adapt to milk during the early phase of cheese manufacture. The lengths of the latency phase $(\lambda)$ were $0.51 \pm 0.08,1.45 \pm 0.11$, and $3.88 \pm 0.09 \mathrm{~h}$ for L. casei LC01, L. plantarum CC3M8, and L. paracasei CC3M35, respectively. The range for $\mu_{\max }$ was 0.11 to $0.16 \Delta \log _{10} \mathrm{cfu} / \mathrm{mL}$ per hour. Attenuated adjunct cultures started from an initial cell count of $\sim 5.1 \pm 0.1$ $\log _{10} \mathrm{cfu} / \mathrm{mL}$ and, after $80 \mathrm{~h}$ of incubation on sterile skim milk, reached an average value of cell viability $\left(9.1 \pm 0.3 \log _{10} \mathrm{cfu} / \mathrm{mL}\right)$ only slightly lower than that of untreated cells. Compared with that in AC cells, the values of $\lambda$ in AAC increased markedly to $3.17 \pm 0.15$, $2.69 \pm 0.1$, and $5.39 \pm 0.09 \mathrm{~h}$ for L. casei LC01, L. plantarum CC3M8, and L. paracasei CC3M35, respectively. The increase in the latency phase was related to sonication treatment and, likely, to the injury of cells. Under these conditions, the growth of L. plantarum CC3M8 was the fastest. The range for $\mu_{\max }$ was 0.14 to $0.18 \Delta$ $\log _{10} \mathrm{cfu} / \mathrm{mL}$ per hour. By the end of the incubation period, the values of $\Delta \mathrm{pH}$ were almost similar for the untreated AC (range of 1.85 to 2.08 units) and sonicated AAC (range of 1.92 to 2.32 units) cells (Figure 1). Nevertheless, the kinetics of acidification were very different. Moreover, because of the sonication treatment, the latency phase of acidification $(\lambda)$ increased markedly (4 to 20 times) from AC to AAC: $3.99 \pm 0.11$ to $19.32 \pm 1.05,4.61 \pm 0.12$ to $45.34 \pm 1.72$, and $2.36 \pm$ 0.05 to $39.78 \pm 1.44 \mathrm{~h}$ for $L$. casei LC01, L. plantarum CC3M8, and L. paracasei CC3M35, respectively. The values of $\mathrm{V}_{\max }$ varied only slightly between $\mathrm{AC}$ (range of 0.08 to $0.11 \mathrm{dpH} / \mathrm{h}$ ) and AAC (range of 0.04 to 0.11 $\mathrm{dpH} / \mathrm{h}$ ). The same trend was found during growth on MRS broth (data not shown).

We compared AC and AAC (same cell count of $\sim 9.0$ $\log _{10} \mathrm{cfu} / \mathrm{mL}$ before sonication treatment) in vitro for activities of several enzymes related to cheese ripening (Gobbetti et al., 1999; Table 1). Except for activity of glutamate dehydrogenase of $L$. casei LC01 and $L$. plantarum CC3M8, and that of endopeptidase type O of L. plantarum CC3M8, all other activities (especially aminopeptidase type $\mathrm{N}$, proline iminopeptidase, and cystathionine lyase) were markedly higher in AAC compared with AC. It appeared that treatment by sonication severely damaged the cell membrane, which resulted in the release of intracellular enzymes and thus higher activities compared with AC.

As shown by plate count, the number of cultivable cells of $L$. plantarum CC3M8 increased progressively from $5.1 \pm 0.1 \log _{10} \mathrm{cfu} / \mathrm{mL}\left(\right.$ at $0 \mathrm{~h}$ ) to $8.8 \pm 0.2 \log _{10}$
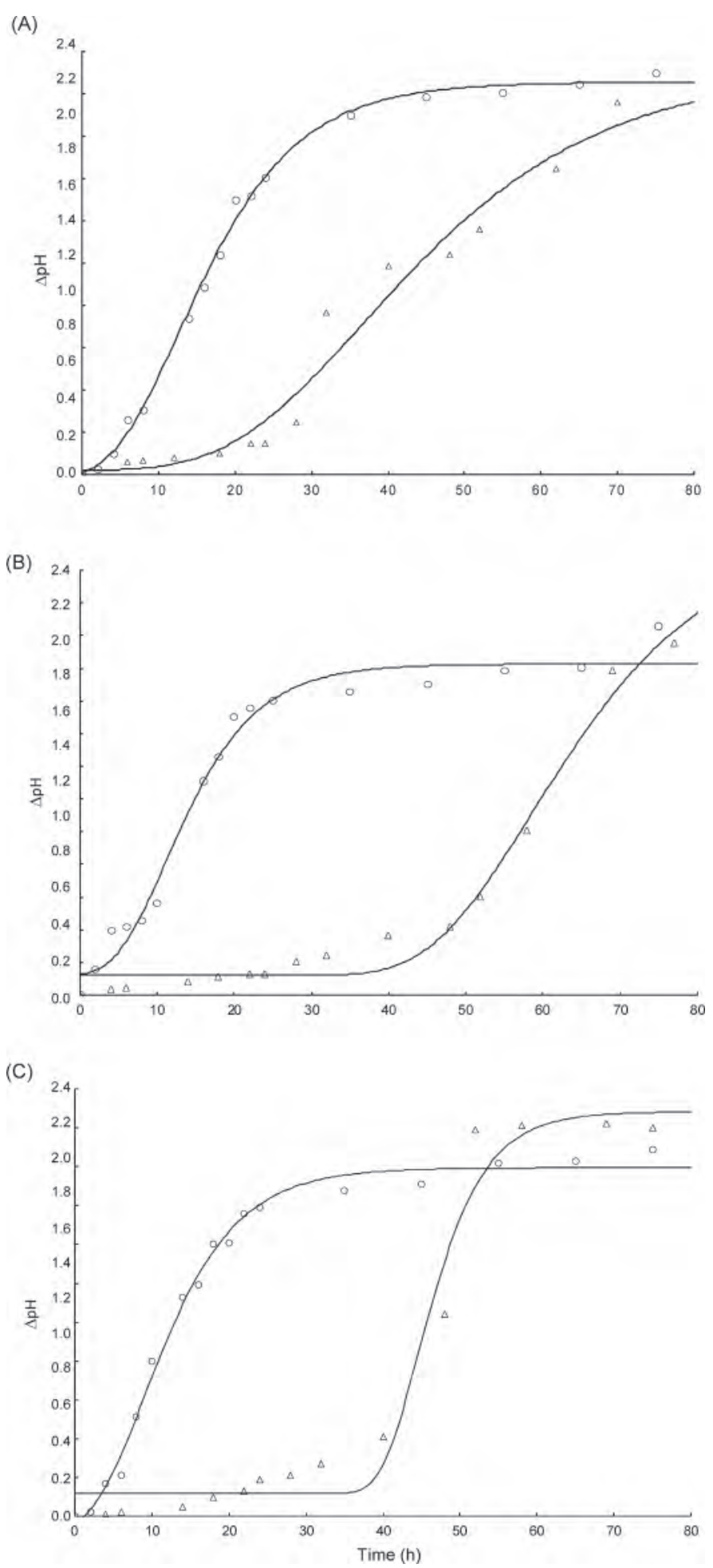

Figure 1. Kinetics of acidification $(\Delta \mathrm{pH})$ of Lactobacillus casei LC01 (A), Lactobacillus plantarum CC3M8 (B), and Lactobacillus paracasei CC3M35 (C) incubated as adjunct ( $\mathrm{O}$; cell count of $\sim 7.0 \log _{10}$ $\mathrm{cfu} / \mathrm{mL})$ or attenuated adjunct cultures $(\Delta$; cell count before sonication treatment of $\sim 9.0 \pm 0.2 \log _{10} \mathrm{cfu} / \mathrm{mL}$, corresponding to $\sim 5.1 \pm$ $0.1 \log _{10} \mathrm{cfu} / \mathrm{mL}$ of cultivable cells) in sterile skim milk at $30^{\circ} \mathrm{C}$ for 80 h. Data are the mean of 3 independent experiments $(n=3)$ analyzed in duplicate. 
Table 1. Enzyme activities ${ }^{1}$ of Lactobacillus casei LC01, Lactobacillus plantarum CC3M8, and Lactobacillus paracasei CC3M35 used as adjunct cultures or attenuated adjunct cultures

\begin{tabular}{|c|c|c|c|c|c|c|}
\hline \multirow[b]{2}{*}{ Enzyme } & \multicolumn{3}{|c|}{ Adjunct culture } & \multicolumn{3}{|c|}{ Attenuated adjunct culture } \\
\hline & $\mathrm{LC} 01$ & CC3M8 & CC3M35 & LC01 & CC3M8 & CC3M35 \\
\hline Aminopeptidase type $\mathrm{N}$ & $17 \pm 0.68^{\mathrm{a}}$ & $6.2 \pm 0.25^{\mathrm{b}}$ & $160 \pm 6.4^{\mathrm{a}}$ & $138 \pm 5.52^{\mathrm{a}}$ & $11.5 \pm 0.46^{\mathrm{b}}$ & $440 \pm 17.6^{\mathrm{a}}$ \\
\hline Endopeptidase type O & $0.02 \pm 0.001^{\mathrm{c}}$ & $0.03 \pm 0.001^{\mathrm{c}}$ & $0.005 \pm 0.001^{\mathrm{c}}$ & $0.24 \pm 0.40^{\mathrm{d}}$ & $0.03 \pm 0.001^{\mathrm{d}}$ & $0.03 \pm 0.001^{\mathrm{d}}$ \\
\hline Glutamate dehydrogenase & $4 \pm 0.16^{\mathrm{b}}$ & $0 \pm 0.00^{\mathrm{d}}$ & $0 \pm 0.00^{\mathrm{d}}$ & $3.3 \pm 0.13^{\mathrm{c}}$ & $0 \pm 0.00^{\mathrm{e}}$ & $2.25 \pm 0.10^{\mathrm{b}}$ \\
\hline Cystathionine lyase & $0 \pm 0.00^{\mathrm{c}}$ & $12.1 \pm 0.49^{\mathrm{a}}$ & $0.1 \pm 0.0^{\mathrm{b}}$ & $17.2 \pm 0.70^{\mathrm{b}}$ & $34.3 \pm 1.37^{\mathrm{a}}$ & $0.44 \pm 0.02^{\mathrm{c}}$ \\
\hline
\end{tabular}

${ }^{\mathrm{a} e}$ Means within a row with different superscript letters are significantly different $(P<0.05)$.

${ }^{1}$ Arbitrary units (see Materials and Methods). Values represent the average of 3 triplicates $( \pm \mathrm{SD})$ from 2 repeated cell cultivations.

$\mathrm{cfu} / \mathrm{mL}$ (at $24 \mathrm{~h}$ ) during incubation in MRS broth. The analysis by bacterial viability kit and the related quantification with the Image-Pro Plus image software (Figure 2) showed that the number of intact cells (green fluorescing) progressively increased to $\sim 8.5 \pm 0.1 \log _{10}$ $\mathrm{cfu} / \mathrm{mL}(24 \mathrm{~h})$. After inoculation, the estimated number of dead or damaged cells (red fluorescing) of $L$. plantarum CC3M8 was $\sim 7.0 \log _{10} \mathrm{cfu} / \mathrm{mL}$, which did not vary throughout $24 \mathrm{~h}$ of incubation. These findings showed that a considerable proportion of L. plantarum CC3M8 cells were subjected to cell membrane injury. Similar results were found for the other 2 strains of lactobacilli (data not shown). Only a few studies (Upadhyay et al., 2007) have characterized in vitro the effect of attenuation treatment and determined the further behavior of attenuated cells. The lactase dehydrogenase was previously used as the marker to show cell lysis. In this study, the use of the LIVE/DEAD BacLight Bacterial Viability Kit, together with analysis of enzyme activities, allowed us to estimate the proportions of intact and damaged cells of AAC, which may differently affect the cheese during ripening.

\section{Cheese Compositional and Microbiological Analyses}

As expected, the use of $\mathrm{AC}$ affected the $\mathrm{pH}$ in the manufacture of Caciocavallo Pugliese cheese (Table 2). Compared with the $\mathrm{CC}(\mathrm{pH} 5.23 \pm 0.10)$ and AAC $(\mathrm{pH} 5.25 \pm 0.12)$ cheeses, the cheese with $\mathrm{AC}$ added had a $\mathrm{pH}$ of $5.03 \pm 0.08$ at the beginning of ripening. Overall, these differences of $\mathrm{pH}$ were almost constant until $45 \mathrm{~d}$ of ripening. During the last $20 \mathrm{~d}$ of ripening, the values of $\mathrm{pH}$ slightly increased for all cheeses and the differences among them were attenuated, from $5.19 \pm 0.07$ and $5.14 \pm 0.09$ (CC and AAC) to 5.05 $\pm 0.03(\mathrm{AC})$. The use of AAC did not affect the $\mathrm{pH}$ or gross composition of the cheese compared with CC, and this is one of the main prerequisites for $\mathrm{AAC}$ to be successfully used (Madkor et al., 2000; Upadhyay and McSweeney, 2003). Impaired AAC could be due to the effects of sonication treatment on enzymes involved in lactose phosphorylation or transportation (Casal and Gomez, 1999). At the end of ripening (60 d), the values of moisture, fat, protein, and salt for $\mathrm{CC}$ and $\mathrm{AAC}$ cheeses were in the range of those usually found during Caciocavallo Pugliese cheesemaking (Ottogalli, 2001). The cheese made with $\mathrm{AC}$ showed a lower value of moisture $(33.8 \pm 1.6 \%)$, which slightly interfered with the concentrations of fat and protein.

Caciocavallo Pugliese cheese was made with raw cow milk, and stretching of the curd in hot water $\left(80^{\circ} \mathrm{C}\right)$ was performed. The latter step had a negative effect on the added mesophilic lactic acid bacteria (Table 3). The $\mathrm{CC}$ cheese had the lowest initial cell count $(3.5 \pm 0.3$ $\left.\log _{10} \mathrm{cfu} / \mathrm{g}\right)$ of presumptive nonstarter mesophilic lactic acid bacteria, which increased during ripening to a value of $7.6 \pm 0.3 \log _{10} \mathrm{cfu} / \mathrm{g}$. The cheese manufactured with the addition of $\mathrm{AC}$ had the highest $(P<0.05)$ initial number of presumptive nonstarter mesophilic lactic acid bacteria $\left(6.2 \pm 0.3 \log _{10} \mathrm{cfu} / \mathrm{g}\right)$, which increased to reach a value of $8.7 \pm 0.3 \log _{10} \mathrm{cfu} / \mathrm{g}$ at the end of ripening. At the beginning of ripening, the cheese manufactured with the addition of AAC contained 4.1 $\pm 0.3 \log _{10} \mathrm{cfu} / \mathrm{g}$ of cultivable nonstarter lactic acid bacteria. After whey drainage, a considerable proportion of AAC presumably became entrapped in the cheese curd drainage (Madkor et al., 2000; Upadhyay and McSweeney, 2003). The cell numbers of AAC increased progressively, especially between 15 and $30 \mathrm{~d}$, and remained almost constant thereafter at $8.4 \pm 0.3 \log _{10}$ $\mathrm{cfu} / \mathrm{g}$. Presumptive mesophilic nonstarter lactic acid bacteria randomly isolated from the highest MRS agar plate dilution were subjected to RAPD-PCR typing. Cheeses manufactured with the addition of AC or AAC contained L. casei LC01, L. plantarum CC3M8, and $L$. paracasei CC3M35, which were capable of withstanding stretching of the curd. Previously (Morea et al., 2007), strains of Lactobacillus parabuchneri used as adjunct cultures were not recovered during ripening of Caciocavallo Pugliese cheese. As shown for other attenuation treatments (Upadhyay et al., 2007), a sufficient number of intact cells was probably capable of further growth 
A
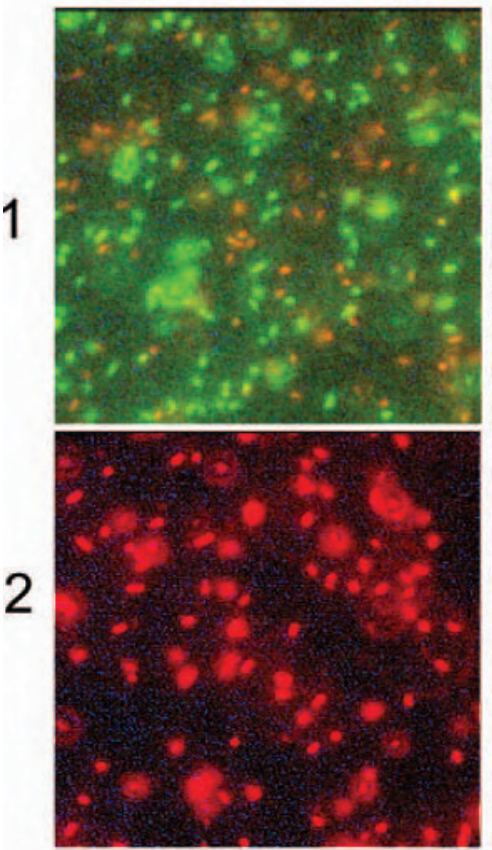

B
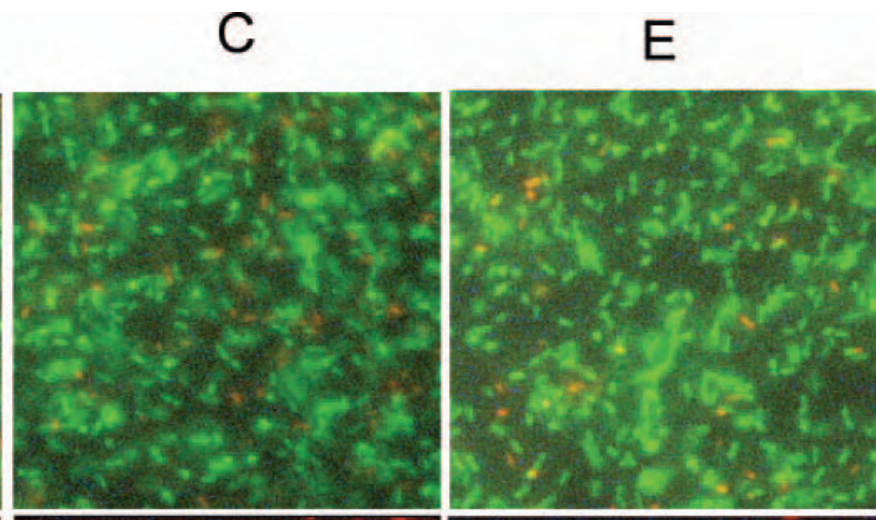

G

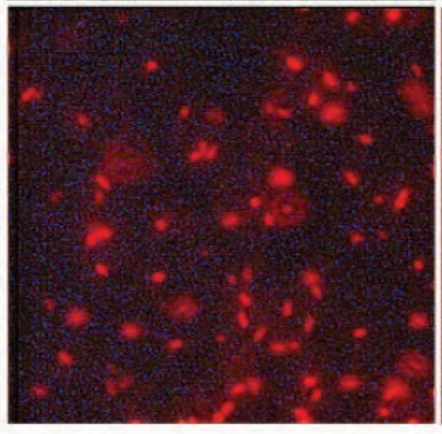

D

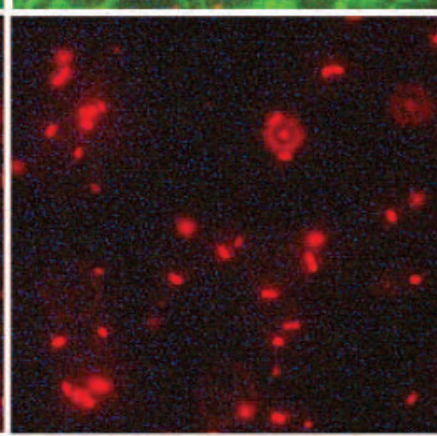

F
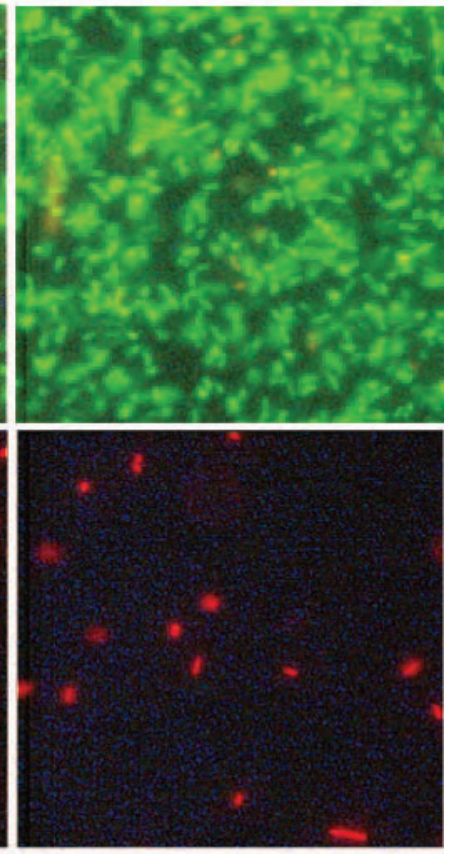

$\mathrm{H}$

Figure 2. Fluorescing Lactobacillus plantarum CC3M8 cells. Intact and dead/damaged cells are stained green (row 1) and red (row 2), respectively. Lactobacillus plantarum CC3M8 was grown in de Man, Rogosa, and Sharpe (MRS) broth at $30^{\circ} \mathrm{C}$ for 0 (A and B), 7 (C and D), 10 (E and F), and $24(\mathrm{G}$ and $\mathrm{H}) \mathrm{h}$.

during cheese ripening. The opposite was found following attenuation by freeze-shocking, heat-shocking, or spray-drying on Lactobacillus helveticus and L. casei strains (Madkor et al., 2000). Overall, cheeses made with additions of $\mathrm{AC}$ or $\mathrm{AAC}$ contained a similar number of NSLAB and the starter species, which are usually found during ripening of Caciocavallo Pugliese or other varieties of Caciocavallo cheeses (Gobbetti et al., 2002; Piraino et al., 2005). The number of presumptive thermophilic streptococci was almost the same for the 3 types of Caciocavallo Pugliese cheese (Table 3). The cell count of thermophilic streptococci decreased slightly during ripening and reached values of $8.7 \pm 0.3$ to $8.9 \pm 0.2 \log _{10} \mathrm{cfu} / \mathrm{g}$ at $60 \mathrm{~d}$, similar to values were found in other Caciocavallo cheeses manufactured in southern Italy (Piraino et al., 2005). In contrast to previous studies (Di Cagno et al., 2011), NSLAB, in either $\mathrm{AC}$ or AAC, did not interfere with the viability of primary starters (in this case, Streptococcus thermophilus).

\section{Proteolysis}

Urea-PAGE electrophoresis of the $\mathrm{pH}$ 4.6-insoluble nitrogen fraction showed a few differences between pri- mary proteolysis of the 3 cheeses (Figure 3A). Although some $\alpha_{\mathrm{S}^{-}} \mathrm{CN}$ persisted in the $\mathrm{CC}$, it was completely degraded after $60 \mathrm{~d}$ in cheeses ripened with the additions of AC or AAC. At the end of ripening, a large amount of nonhydrolyzed $\beta$-CN persisted in all cheeses. As shown in previous studies (Farkye and Fox, 1990; Milanovic et al., 1998; Gobbetti et al., 2002), plasmin activity would be expected during primary proteolysis of ripened pasta filata cheeses. Although a debatable point, chymosin should be fully inactivated by scalding at $80^{\circ} \mathrm{C}$. Starting from $30 \mathrm{~d}$, the urea-PAGE electrophoresis of the $\mathrm{pH}$ 4.6-soluble nitrogen fraction slightly differed between $\mathrm{CC}$ and the cheeses manufactured with AAC (Figure 3B). In particular, the cheese made with AAC showed less intense bands of polypeptides. In contrast to other studies (Madkor et al., 2000), a moderate direct or indirect effect of $\mathrm{AC}$ and $\mathrm{AAC}$ was found during primary proteolysis. The same results were found by RP-HPLC analysis (data not shown).

At the beginning of ripening, no significant $(P>$ $0.05)$ differences were found for the total concentration of FAA among the 3 cheeses $(634.9 \pm 25$ to $685.7 \pm 39$ $\mathrm{mg} / \mathrm{kg}$; Table 4). At the end of ripening, the highest increase $(10,060.1 \pm 40 \mathrm{mg} / \mathrm{kg})$ was found for the cheese 
Table 2. Main chemical composition ${ }^{1}$ during ripening of Caciocavallo Pugliese cheeses

\begin{tabular}{|c|c|c|c|c|c|c|c|c|c|c|c|c|c|c|c|}
\hline \multirow[b]{2}{*}{ Item } & \multicolumn{5}{|c|}{ Control cheese } & \multicolumn{5}{|c|}{ Cheese with adjunct culture } & \multicolumn{5}{|c|}{ Cheese with attenuated adjunct culture } \\
\hline & $0 \mathrm{~d}$ & $15 \mathrm{~d}$ & $30 \mathrm{~d}$ & $45 \mathrm{~d}$ & $60 \mathrm{~d}$ & $0 \mathrm{~d}$ & $15 \mathrm{~d}$ & $30 \mathrm{~d}$ & $45 \mathrm{~d}$ & $60 \mathrm{~d}$ & $0 \mathrm{~d}$ & $15 \mathrm{~d}$ & $30 \mathrm{~d}$ & $45 \mathrm{~d}$ & $60 \mathrm{~d}$ \\
\hline $\mathrm{pH}$ & $\begin{array}{r}5.23 \pm \\
0.1^{\mathrm{a}}\end{array}$ & $\begin{array}{c}5.08 \pm \\
0.15^{\mathrm{b}}\end{array}$ & $\begin{array}{l}4.9 \pm \\
0.11^{\mathrm{c}}\end{array}$ & $\begin{array}{c}4.82 \pm \\
0.09^{\mathrm{d}}\end{array}$ & $\begin{array}{c}5.19 \pm \\
0.07^{\mathrm{b}}\end{array}$ & $\begin{array}{l}5.03 \pm \\
0.08^{\mathrm{bc}}\end{array}$ & $\begin{array}{l}4.87 \pm \\
0.07^{\mathrm{d}}\end{array}$ & $\begin{array}{c}4.72 \pm \\
0.1^{\mathrm{e}}\end{array}$ & $\begin{array}{c}4.6 \pm \\
0.13^{\mathrm{f}}\end{array}$ & $\begin{array}{c}5.05 \pm \\
0.03^{\mathrm{bc}}\end{array}$ & $\begin{array}{l}5.25 \pm \\
0.12^{\mathrm{a}}\end{array}$ & $\begin{array}{c}5.1 \pm \\
0.13^{\mathrm{b}}\end{array}$ & $\begin{array}{c}4.92 \pm \\
0.07^{\mathrm{c}}\end{array}$ & $\begin{array}{l}4.8 \pm \\
0.03^{\mathrm{d}}\end{array}$ & $\begin{array}{c}5.14 \pm \\
0.09^{\mathrm{b}}\end{array}$ \\
\hline Moisture (\%) & $\begin{array}{c}43.5 \pm \\
1.2^{\mathrm{a}}\end{array}$ & $\begin{array}{c}39.3 \pm \\
1.1^{\mathrm{bc}}\end{array}$ & $\begin{array}{c}38.5 \pm \\
1.0^{c}\end{array}$ & $\begin{array}{c}37.7 \pm \\
1.1^{\mathrm{d}}\end{array}$ & $\begin{array}{r}37.4 \pm \\
1.2^{\mathrm{d}}\end{array}$ & $\begin{array}{c}40.8 \pm \\
1.1^{\mathrm{b}}\end{array}$ & $\begin{array}{c}36.5 \pm \\
1.0^{\mathrm{e}}\end{array}$ & $\begin{array}{r}35.8 \pm \\
1.3^{\mathrm{e}}\end{array}$ & $\begin{array}{c}34.2 \pm \\
1.4^{\mathrm{f}}\end{array}$ & $\begin{array}{r}33.8 \pm \\
1.6^{\mathrm{f}}\end{array}$ & $\begin{array}{r}43.1 \pm \\
1.4^{\mathrm{a}}\end{array}$ & $\begin{array}{c}39.0 \pm \\
1.4^{\mathrm{bc}}\end{array}$ & $\begin{array}{c}38.1 \pm \\
1.1^{\mathrm{c}}\end{array}$ & $\begin{array}{c}37.4 \pm \\
1.3^{\mathrm{d}}\end{array}$ & $\begin{array}{r}37.0 \pm \\
1.5^{\mathrm{d}}\end{array}$ \\
\hline Fat $(\%)$ & $\begin{array}{l}40.1 \pm \\
1.1^{\mathrm{d}}\end{array}$ & $\begin{array}{r}41.5 \pm \\
1.3^{\mathrm{c}}\end{array}$ & $\begin{array}{r}41.8 \pm \\
1.5^{\mathrm{c}}\end{array}$ & $\begin{array}{c}42.0 \pm \\
1.5^{\mathrm{b}}\end{array}$ & $\begin{array}{c}42.3 \pm \\
1.8^{\mathrm{b}}\end{array}$ & $\begin{array}{r}41.9 \pm \\
1.5^{\mathrm{c}}\end{array}$ & $\begin{array}{r}42.9 \pm \\
1.7^{\mathrm{a}}\end{array}$ & $\begin{array}{r}43.3 \pm \\
0.9^{\mathrm{a}}\end{array}$ & $\begin{array}{r}43.6 \pm \\
1.1^{\mathrm{a}}\end{array}$ & $\begin{array}{r}43.9 \pm \\
0.7^{\mathrm{a}}\end{array}$ & $\begin{array}{r}40.3 \pm \\
1.0^{\mathrm{d}}\end{array}$ & $\begin{array}{r}41.2 \pm \\
1.0^{c}\end{array}$ & $\begin{array}{r}41.7 \pm \\
0.9^{\mathrm{c}}\end{array}$ & $\begin{array}{c}42.2 \pm \\
1.1 \mathrm{a}^{\mathrm{b}}\end{array}$ & $\begin{array}{c}42.5 \pm \\
1.2^{\mathrm{b}}\end{array}$ \\
\hline Protein $(\%)$ & $\begin{array}{r}41.0 \pm \\
0.8^{\mathrm{d}}\end{array}$ & $\begin{array}{r}42.1 \pm \\
1.0^{c}\end{array}$ & $\begin{array}{c}42.3 \pm \\
1.1^{\mathrm{c}}\end{array}$ & $\begin{array}{c}42.6 \pm \\
0.9^{\mathrm{bc}}\end{array}$ & $\begin{array}{r}42.9 \pm \\
1.0^{\mathrm{b}}\end{array}$ & $\begin{array}{r}42.1 \pm \\
0.9^{c}\end{array}$ & $\begin{array}{c}43.5 \pm \\
1.0^{\mathrm{b}}\end{array}$ & $\begin{array}{r}43.9 \pm \\
0.8^{\mathrm{b}}\end{array}$ & $\begin{array}{r}44.3 \pm \\
0.9^{\mathrm{a}}\end{array}$ & $\begin{array}{r}44.7 \pm \\
0.5^{\mathrm{a}}\end{array}$ & $\begin{array}{r}41.2 \pm \\
0.8^{\mathrm{d}}\end{array}$ & $\begin{array}{r}42.3 \pm \\
1.1^{c}\end{array}$ & $\begin{array}{r}42.5 \pm \\
1.2^{\mathrm{c}}\end{array}$ & $\begin{array}{r}42.9 \pm \\
0.9^{c}\end{array}$ & $\begin{array}{r}43.1 \pm \\
1.7^{\mathrm{b}}\end{array}$ \\
\hline $\mathrm{NaCl}(\%)$ & $\begin{array}{c}1.91 \pm \\
0.1^{\mathrm{d}}\end{array}$ & $\begin{array}{r}1.99 \pm \\
0.1^{\mathrm{c}}\end{array}$ & $\begin{array}{c}2.0 \pm \\
0.2^{\mathrm{b}}\end{array}$ & $\begin{array}{c}2.1 \pm \\
0.1^{\mathrm{b}}\end{array}$ & $\begin{array}{l}2.2 \pm \\
0.2^{\mathrm{b}}\end{array}$ & $\begin{array}{l}2.1 \pm \\
0.2^{\mathrm{b}}\end{array}$ & $\begin{array}{c}2.31 \pm \\
0.1^{\mathrm{ab}}\end{array}$ & $\begin{array}{r}2.36 \pm \\
0.2^{\mathrm{a}}\end{array}$ & $\begin{array}{c}2.38 \pm \\
0.2^{\mathrm{a}}\end{array}$ & $2.4 \pm 0.2^{\mathrm{a}}$ & $\begin{array}{c}1.89 \pm \\
0.1^{\mathrm{e}}\end{array}$ & $\begin{array}{c}1.95 \pm \\
0.1^{\mathrm{cd}}\end{array}$ & $\begin{array}{r}1.97 \pm \\
0.1^{\mathrm{c}}\end{array}$ & $\begin{array}{r}1.98 \pm \\
0.1^{\mathrm{c}}\end{array}$ & $\begin{array}{c}2.0 \pm \\
0.1^{\mathrm{b}}\end{array}$ \\
\hline
\end{tabular}

${ }^{\mathrm{a}-\mathrm{f}}$ Means within a row with different superscript letters are significantly different $(P<0.05)$.

${ }^{1}$ Mean values $\pm \mathrm{SD}$ for 3 batches of each type of cheese analyzed in duplicate.

Table 3. Cell numbers $\left(\log _{10} \mathrm{cfu} / \mathrm{g}\right)^{1}$ of presumptive mesophilic lactobacilli and thermophilic streptococci during ripening of Caciocavallo Pugliese cheeses

Cheese with adjunct culture

Control cheese

Cheese with attenuated adjunct culture

\begin{tabular}{|c|c|c|c|c|c|c|c|c|c|c|c|c|c|c|c|}
\hline Item & $0 \mathrm{~d}$ & $15 \mathrm{~d}$ & $30 \mathrm{~d}$ & $45 \mathrm{~d}$ & $60 \mathrm{~d}$ & $0 \mathrm{~d}$ & $15 \mathrm{~d}$ & $30 \mathrm{~d}$ & $45 \mathrm{~d}$ & $60 \mathrm{~d}$ & $0 \mathrm{~d}$ & $15 \mathrm{~d}$ & $30 \mathrm{~d}$ & $45 \mathrm{~d}$ & $60 \mathrm{~d}$ \\
\hline Mesophilic lactobacilli & $\begin{array}{c}3.5 \pm \\
0.3^{\mathrm{d}}\end{array}$ & $\begin{array}{c}4.9 \pm \\
0.3^{\mathrm{d}}\end{array}$ & $\begin{array}{c}6.7 \pm \\
0.4^{\mathrm{b}}\end{array}$ & $\begin{array}{l}7.2 \pm \\
0.4^{\mathrm{a}}\end{array}$ & $\begin{array}{c}7.6 \pm \\
0.3^{\mathrm{c}}\end{array}$ & $\begin{array}{c}6.2 \pm \\
0.3^{b}\end{array}$ & $\begin{array}{c}8.4 \pm \\
0.4^{\mathrm{b}}\end{array}$ & $\begin{array}{c}8.6 \pm \\
0.3^{\mathrm{b}}\end{array}$ & $\begin{array}{c}8.5 \pm \\
0.3^{\mathrm{b}}\end{array}$ & $\begin{array}{c}8.7 \pm \\
0.3^{b}\end{array}$ & $\begin{array}{c}4.1 \pm \\
0.3^{\mathrm{c}}\end{array}$ & $\begin{array}{c}6.6 \pm \\
0.4^{\mathrm{b}}\end{array}$ & $\begin{array}{c}8.4 \pm \\
0.3^{\mathrm{b}}\end{array}$ & $\begin{array}{c}8.5 \pm \\
0.4^{\mathrm{a}}\end{array}$ & $\begin{array}{c}8.4 \pm \\
0.3^{\mathrm{b}}\end{array}$ \\
\hline Thermophilic streptococci & $\begin{array}{c}9.3 \pm \\
0.4^{\mathrm{b}}\end{array}$ & $\begin{array}{c}9.5 \pm \\
0.4^{\mathrm{a}}\end{array}$ & $\begin{array}{c}9.4 \pm \\
0.4^{\mathrm{a}}\end{array}$ & $\begin{array}{r}9.6 \pm \\
0.4^{\mathrm{a}}\end{array}$ & $\begin{array}{c}8.9 \pm \\
0.4^{\mathrm{c}}\end{array}$ & $\begin{array}{c}9.5 \pm \\
0.4^{\mathrm{a}}\end{array}$ & $\begin{array}{c}9.4 \pm \\
0.4^{\mathrm{a}}\end{array}$ & $\begin{array}{c}9.6 \pm \\
0.4^{\mathrm{a}}\end{array}$ & $\begin{array}{c}9.5 \pm \\
0.4^{\mathrm{c}}\end{array}$ & $\begin{array}{c}8.6 \pm \\
0.3^{\mathrm{c}}\end{array}$ & $\begin{array}{c}9.5 \pm \\
0.4^{\mathrm{a}}\end{array}$ & $\begin{array}{r}9.1 \pm \\
0.4^{\mathrm{b}}\end{array}$ & $\begin{array}{l}9.4 \pm \\
0.4^{\mathrm{a}}\end{array}$ & $\begin{array}{c}9.5 \pm \\
0.4^{\mathrm{a}}\end{array}$ & $\begin{array}{r}8.7 \pm \\
0.3^{c}\end{array}$ \\
\hline
\end{tabular}

${ }^{\mathrm{a}-\mathrm{d}}$ Means within a row with different superscript letters are significantly different $(P<0.05)$

${ }^{1}$ Mean values $\pm \mathrm{SD}$ for 3 batches of each type of cheese analyzed in duplicate. 
(A)

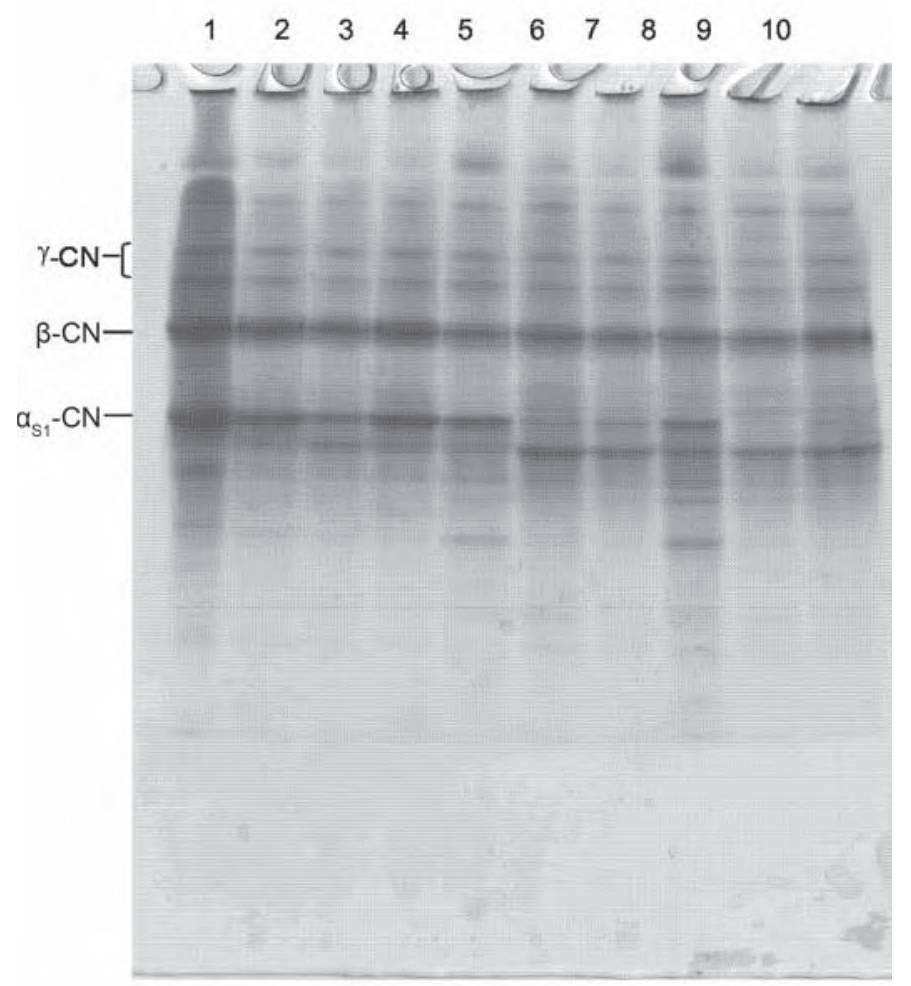

(B)

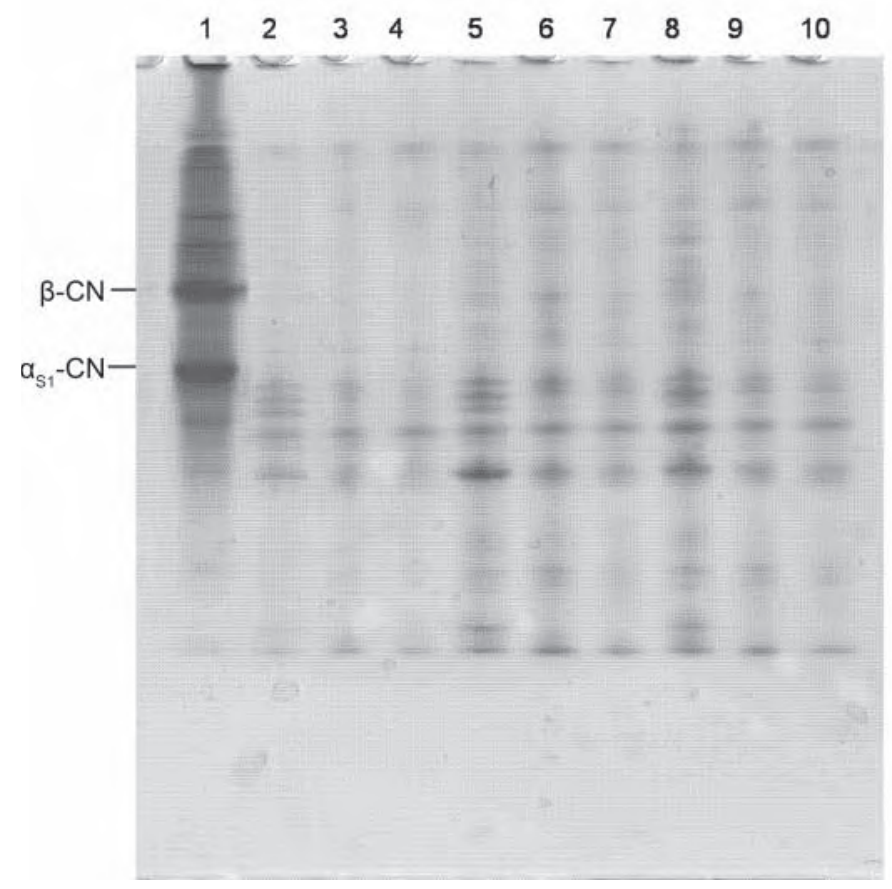

Figure 3. Urea-PAGE of $\mathrm{pH}$ 4.6-insoluble (A) and $\mathrm{pH} 4.6$-soluble (B) nitrogen fraction of Caciocavallo Pugliese cheeses after 0,30, and $60 \mathrm{~d}$ of ripening. Lane $1=$ bovine $\mathrm{CN}$ standard; lanes 2, 3, and $4=$ control cheese (CC), cheese with adjunct cultures (AC), and cheese with attenuated adjunct cultures (AAC) after $0 \mathrm{~d}$ of ripening; lanes 5 , 6 , and $7=\mathrm{CC}, \mathrm{AC}$, and $\mathrm{AAC}$ after $30 \mathrm{~d}$ of ripening; and lanes 8, 9, and $10, \mathrm{CC}, \mathrm{AC}$, and $\mathrm{AAC}$ after $60 \mathrm{~d}$ of ripening. made with the addition of AAC. This concentration was approximately 5 times higher than that found in $\mathrm{CC}(1,655.2 \pm 25 \mathrm{mg} / \mathrm{kg})$ and twice that found in the cheese manufactured with $\mathrm{AC}(5,875.5 \pm 23 \mathrm{mg} / \mathrm{kg})$. Previously (Morea et al., 2007), the concentration of total FAA of Caciocavallo Pugliese cheese made with the addition of L. paracasei and L. parabuchneri strains was found to be $20,954 \mathrm{mg} / \mathrm{kg}$. Several studies reported accelerated or increased liberation of FAA when adjunct or attenuated starters were used in cheese manufacture (Ardö et al., 1989; Madkor et al., 2000; Katsiari et al., 2002; Michaelidou et al., 2003; Upadhyay et al., 2007). Accelerated liberation of most FAA in cheeses promotes increased synthesis of volatile compounds and markedly influences the flavor of cheeses (Fox and Wallace, 1997). It was previously shown (Madkor et al., 2000) that the liberation of FAA by attenuated adjunct cultures is highest after approximately 1 mo of ripening, which corresponds to the time needed to attain a significant extent of cell autolysis. Serine, Glu, Leu, Phe, Lys, and Pro were the FAA found at the highest concentrations, especially in the Caciocavallo Pugliese cheese manufactured with the addition of AAC in the current study. These FAA corresponded to the most common profiles of FAA for Italian cheese varieties (Resmini et al., 1988; Gobbetti et al., 1999; Albenzio et al., 2001; Di Cagno et al., 2003).

Concentrations of the same enzyme activities that were previously used to select nonstarter lactobacilli were determined in the water-soluble extracts of the cheeses during ripening (Figure 4, panels A to E). All of these enzymes are important in secondary proteolysis and the catabolism of FAA (Gobbetti et al., 1999). A well-defined trend was observed: all enzyme activities were highest in the cheese manufactured with AAC, and the largest significant $(P<0.05)$ differences were found at $30 \mathrm{~d}$ of ripening. The enzyme activity levels in AAC cheese were at least twice those found in CC. Further, cystathionine lyase activity was detectable in all cheeses but only at the end of ripening in CC. These results might be related to several of the previous findings. As shown through in vitro characterization, a portion of the AAC population was severally damaged, which promoted the liberation of enzymes in the curd. The remaining viable portion of the AAC population continued to grow over the same period of ripening and may have contributed, even to a small degree, to the activity of the enzymes measured. Moreover, a contribution from autolysed cells of primary starters cannot be excluded. The concentration of total FAA completely agreed with the differences found for enzyme activities. With the exception of proline iminopeptidase activity, the enzyme activities found in the cheese manufactured with AC were significantly $(P<0.05)$ higher than 
Table 4. Mean values ${ }^{1}$ for the level of free AA $(\mathrm{mg} / \mathrm{kg})$ found in Caciocavallo Pugliese cheeses made without adjuncts (control), with adjunct cultures (AC), and with attenuated adjunct cultures (AAC) during ripening

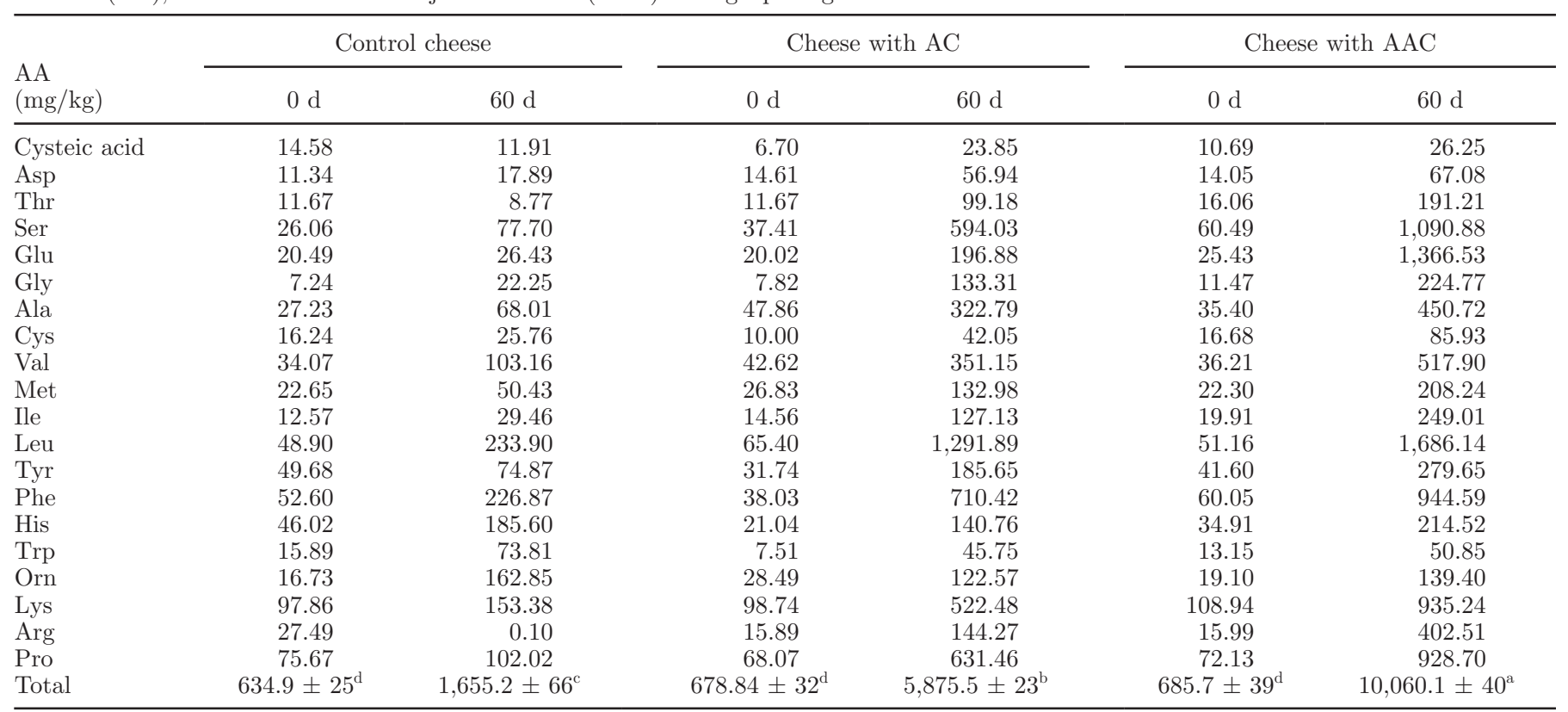

${ }^{\mathrm{a}-\mathrm{d}}$ Means within a row with different superscript letters are significantly different $(P<0.05)$.

${ }^{1}$ Mean values $\pm \mathrm{SD}$ for 3 batches of each type of cheese analyzed in duplicate.

those found in CC. The same was found for peptidase activities in Caciocavallo Pugliese cheese made with other adjunct cultures (Gobbetti et al., 2002).

\section{Sensory Analysis}

Acceleration of ripening under standardized conditions is the major goal of using attenuated adjunct cultures (Johnson et al., 1995; Madkor et al., 1999). It is expected that sensory properties of the cheese when ripening is accelerated would not differ from those achieved under conventional maturation. Based on the above results, the sensory properties of the Caciocavallo Pugliese manufactured with AAC after $45 \mathrm{~d}$ of ripening were compared, by triangle test (ISO, 2004), with those of $\mathrm{CC}$ after $60 \mathrm{~d}$ of ripening. The 2 cheeses did not differ significantly. Only 18 of 42 assessors recognized the 2 cheeses as different, a value lower than the expected number (20) of correct responses $(\alpha=0.05, \beta=0.05$, and $\mathrm{Pd} 40 \%$ ) required to determine that a significant difference was noticeable by panelists. The opposite was found when $\mathrm{CC}$ (60 d of ripening) was compared with $\mathrm{AC}(45 \mathrm{~d})$ and $\mathrm{AC}(45 \mathrm{~d})$ was compared with AAC $(45 \mathrm{~d})$. Based on the same parameters of sensitivity, respectively, 26 and 25 assessors recognized these pairs as being different cheeses. These values were higher than the expected number (20) of correct responses. Based on the results of this study, the use of AAC was suitable for accelerating the ripening of Caciocavallo Pugliese cheese without adverse effects on sensory properties.

\section{CONCLUSIONS}

The NSLAB represent an appreciable source of diversity and enzyme activities to be used in cheesemaking. Nevertheless, their effect on cheese quality is variable depending on the strain and procedure used. Although still contentious, attenuation is one of the most promising procedures to use selected NSLAB under controlled and consistent conditions. This study showed that sonication is useful tool to achieve attenuation. The effect of sonication on the cell membrane integrity of nonstarter lactobacilli was characterized in vitro and confirmed during cheesemaking. Attenuated adjunct cultures were suitable for making ripened pasta filata cheeses such as Caciocavallo Pugliese. As shown through microbiological, biochemical, and sensory analyses, the accelerated ripening of Cacioacavallo Pugliese cheese was achieved without modification of the main features of the traditional cheese made without adjuncts.

\section{ACKNOWLEDGMENTS}

The authors are grateful to the Ignazi family of the Dairy Ignalat (Noci, Bari, Italy) for technical support in cheesemaking. 
A)

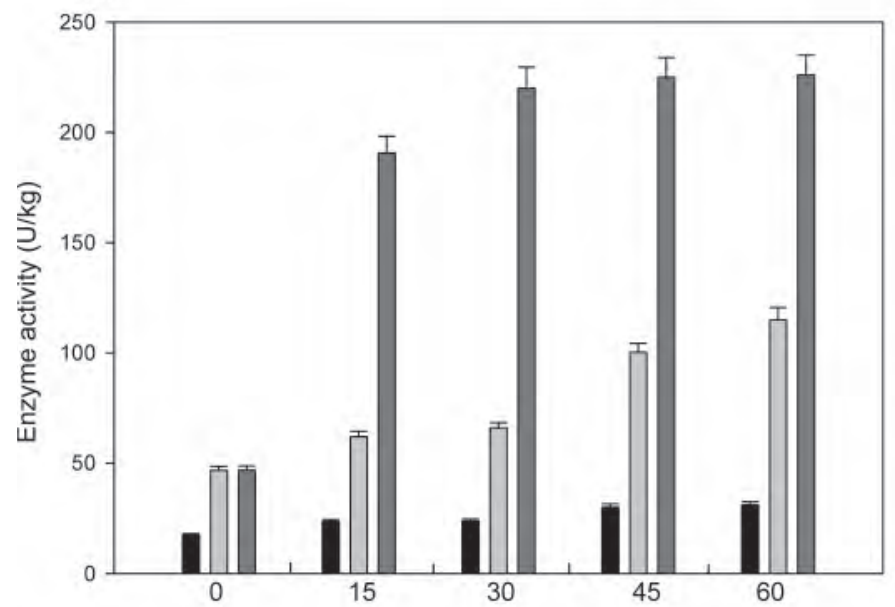

C)

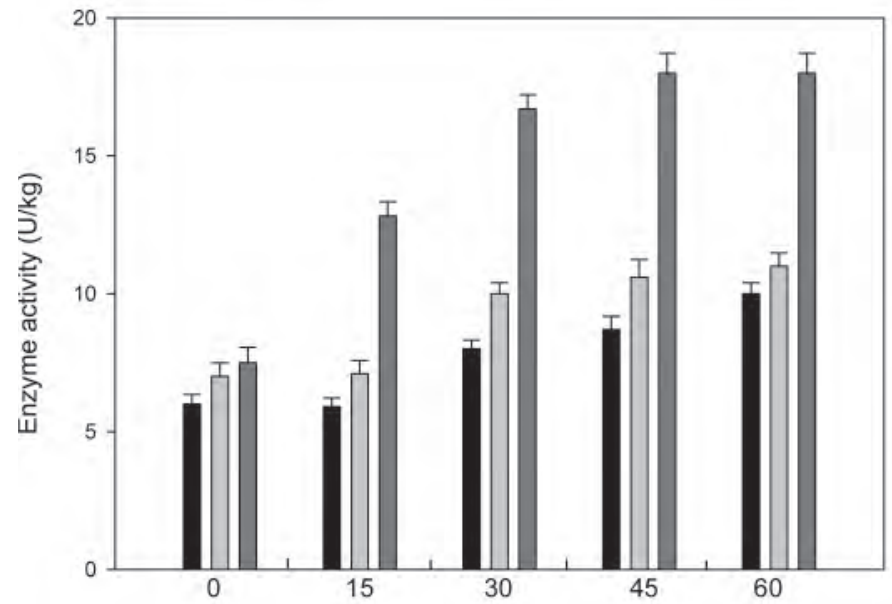

E)

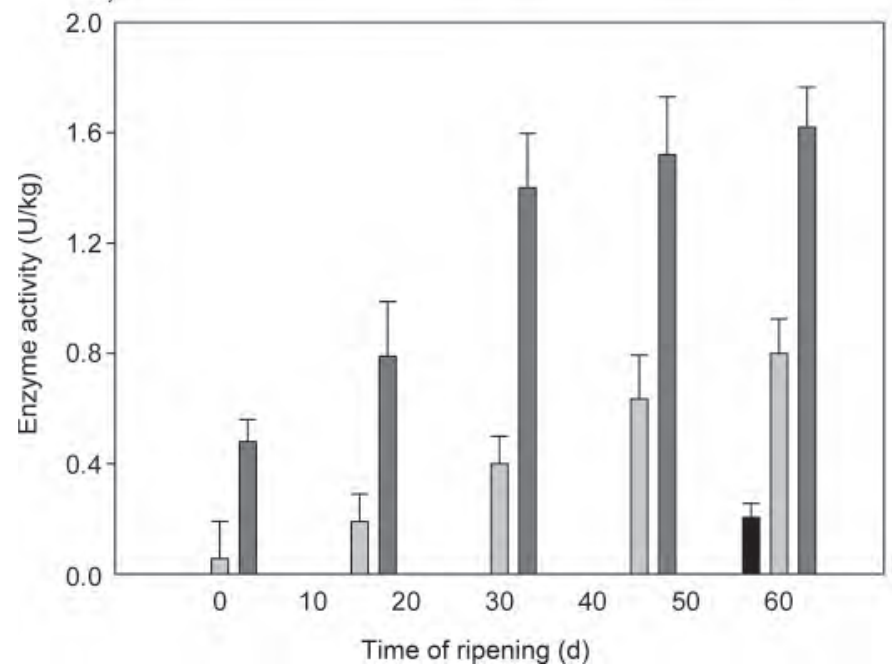

B)

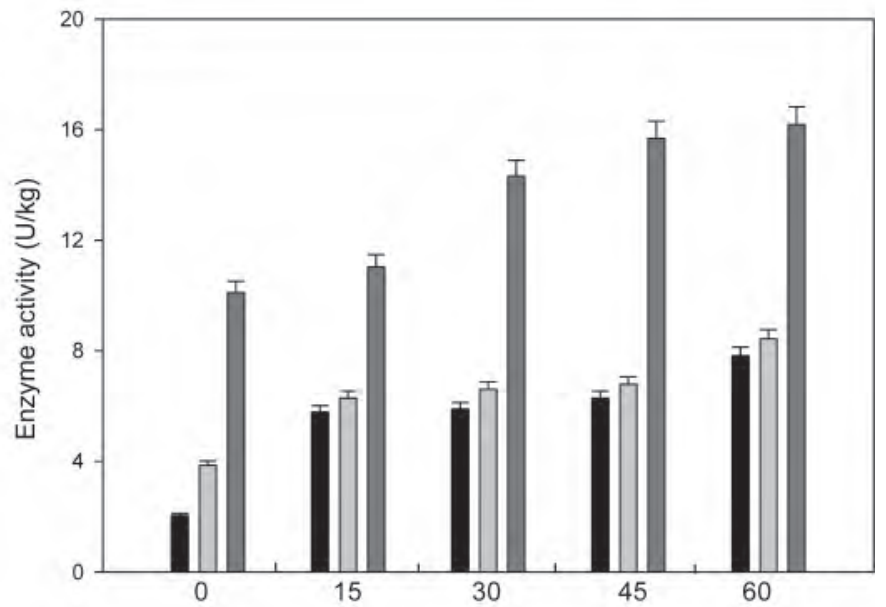

D)

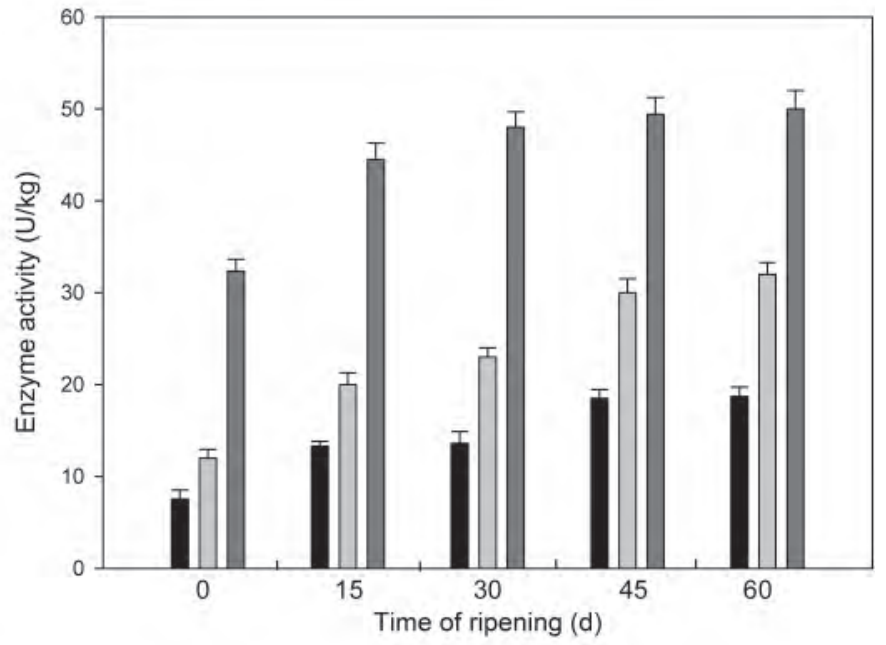

Figure 4. Enzymatic activities (arbitrary units $/ \mathrm{kg}$ ) of water-soluble extracts of Caciocavallo Pugliese cheeses made without adjunct cultures (control; black bars), with adjunct cultures (light gray bars), and with attenuated adjunct cultures (dark gray bars) after $0,15,30,45$, and $60 \mathrm{~d}$ of ripening. Panels show activities of aminopeptidase type N (A), iminopeptidase (B), endopeptidase type O (C), glutamate dehydrogenase (D), and cystathionine lyase $(\mathrm{E})$. Values represent the average of 3 triplicates $( \pm \mathrm{SD})$ from 3 cheese-making experiments. 


\section{REFERENCES}

Albenzio, M., M. R. Corbo, S. U. Rehman, P. F. Fox, M. De Angelis, A. Corsetti, A. Sevi, and M. Gobbetti. 2001. Microbiological and biochemical characteristics of Canestrato Pugliese cheese made from raw milk, pasteurized milk or by heating the curd in hot whey. Int. J. Food Microbiol. 67:35-48.

Ardö, Y., P. O. Larsson, H. Lindmark Mansson, and A. Hedenberg. 1989. Studies on peptidolysis during early maturation and its influence on low-fat cheese quality. Milchwissenschaft 44:485-490.

Biggerstaff, J. P., M. Le Puil, B. L. Weidow, J. Prater, K. Glass, M. Radosevich, and D. C. White. 2006. New methodology for viability testing in environmental samples. Mol. Cell. Probes 20:141-146.

Casal, V., and R. Gomez. 1999. Effect of high pressure on the viability and enzymatic activity of mesophilic lactic acid bacteria isolated from caprine cheese. J. Dairy Sci. 82:1092-1098.

Crow, V., B. Curry, and M. Hayes. 2001. The ecology of non-starter lactic acid bacteria (NSLAB) and their use as adjuncts in New Zealand Cheddar. Int. Dairy J. 11:275-283.

De Angelis, M., M. P. Calasso, R. Di Cagno, F. Minervini, and M. Gobbetti. 2010. NADP-glutamate dehydrogenase activity in nonstarter lactic acid bacteria: Effects of temperature, $\mathrm{pH}$ and $\mathrm{NaCl}$ on enzyme activity and expression. J. Appl. Microbiol. 109:17631774 .

De Angelis, M., A. Corsetti, N. Tosti, J. Rossi, M. R. Corbo, and M. Gobbetti. 2001. Characterization of non-starter lactic acid bacteria from Italian ewe cheese based on phenotypic, genotypic, and cell wall protein analyses. Appl. Environ. Microbiol. 67:2011-2020.

De Angelis, M., A. C. Curtin, P. L. H. McSweeney, M. Faccia, and M. Gobbetti. 2002. Lactobacillus reuteri DSM 20016: Purification and characterization of a cystathionine $\gamma$-lyase and use as adjunct starter in cheesemaking. J. Dairy Res. 69:255-267.

De Angelis, M., S. Siragusa, M. Berloco, L. Caputo, A. Ragni, R. Burzigotti, and M. Gobbetti. 2006. Selection of potential probiotic lactobacilli from pig feces to be used as additives in pelleted feeding. Res. Microbiol. 157:792-801.

de Los Reyes-Gavilán, C. G., G. K. Y. Limsowtin, P. Tailliez, L. Séchaud, and J. P. Accolas. 1992. A Lactobacillus helveticus-specific DNA probe detects restriction fragment length polymorphisms in this species. Appl. Environ. Microbiol. 58:3429-3432.

Di Cagno, R., J. Banks, J. Sheehan, P. F. Fox, E. Y. Brechany, A. Corsetti, and M. Gobbetti. 2003. Comparison of the microbiological, compositional, biochemical, volatile profile and sensory characteristics of three Italian PDO ewes' milk cheeses. Int. Dairy J. 13:961-972.

Di Cagno, R., S. Buchin, S. de Candia, M. De Angelis, P. F. Fox, and M. Gobbetti. 2007. Characterization of Italian cheeses ripened under nonconventional conditions. J. Dairy Sci. 90:2689-2704.

Di Cagno, R., I. De Pasquale, M. De Angelis, S. Buchin, M. Calasso, P. F. Fox, and M. Gobbetti. 2011. Manufacture of Italian Caciottatype cheeses with adjuncts and attenuated adjuncts of selected non-starter lactobacilli. Int. Dairy J. 21:254-260.

Di Cagno, R., M. Quinto, A. Corsetti, F. Minervini, and M. Gobbetti. 2006. Assessing the proteolytic and lypolytic activities of single strains of mesophilic lactobacilli as adjunct cultures using a Caciotta cheese model system. Int. Dairy J. 16:119-130.

Farkye, N. Y., and P. F. Fox. 1990. Observation of plasmin activity in cheese. J. Dairy Res. 57:413-418.

Fox, P. F. 1963. Potentiometric determination of salt in cheese. J. Dairy Sci. 46:744-745.

Fox, P. F., and J. M. Wallace. 1997. Formation of flavour compounds. Adv. Appl. Microbiol. 45:17-85.

Giraffa, G., L. Rossetti, and E. Neviani. 2000. An evaluation of selexbased DNA purification protocols for the typing of lactic acid bacteria. J. Microbiol. Methods 42:175-184.

Gobbetti, M., B. Folkertsma, P. F. Fox, A. Corsetti, E. Smacchi, M. De Angelis, J. Rossi, K. Kilcawley, and M. Cortin. 1999. Microbiology and biochemistry of Fossa (pit) cheese. Int. Dairy J. 9:763-773.

Gobbetti, M., A. Morea, F. Baruzzi, M. R. Corbo, A. Matarante, T. Considine, R. Di Cagno, T. Guinee, and P. F. Fox. 2002. Microbiological, compositional, biochemical and textural characteriza- tion of Caciocavallo Pugliese cheese during ripening. Int. Dairy J. $12: 511-523$.

IDF (International Dairy Federation). 1964. Determination of the protein content of processed cheeses products. Standard 25. International Dairy Federation, Brussels, Belgium.

IDF (International Dairy Federation). 1982. Cheese and processed cheese. Determination of the total solid content. IDF Standard 4A. International Dairy Federation, Brussels, Belgium.

IIRS (Institute for Industrial Research and Standards). 1955. Determination of the percentage of fat in cheese. Irish Standard 69. Institute for Industrial Research and Standards, Dublin. Ireland.

ISO (International Organization for Standardization). 2004. ISO 4120:2004. Sensory analysis-Methodology-Triangle test. International Organization for Standardization, Geneva, Switzerland.

ISO (International Organization for Standardization). 2008. UNI EN ISO 5495:2008. Sensory analysis-Methodology-Paired comparison test. International Organization for Standardization, Geneva, Switzerland.

Johnson, J., M. Etzel, C. Chen, and M. Johnson. 1995. Accelerated ripening of reduced-fat Cheddar cheese using four attenuated $L a c$ tobacillus helveticus CNRZ-32 adjuncts. J. Dairy Sci. 78:769-776.

Katsiari, M. C., L. P. Voutsinas, and E. Kondyli. 2002. Improvement of sensory quality of low-fat Kefalograviera-type cheese with commercial adjunct cultures. Int. Dairy J. 12:757-764.

Klein, N., and S. Lortal. 1999. Attenuated starters: An efficient means to influence cheese ripening - A review. Int. Dairy J. 9:751-762.

Kuchroo, C. N., and P. F. Fox. 1982. Soluble nitrogen in Cheddar cheese: Comparison of extraction procedures. Milchwissenschaft 37:331-335.

Madkor, S. A., M. El-Soda, and P. S. Tong. 1999. Evaluation of commercial adjuncts for use in cheese ripening: 2. Ripening aspects and flavour development in cheese curd slurries prepared with adjunct lactobacilli. Milchwissenchaft 54:133-137.

Madkor, S. A., P. S. Tong, and M. El-Soda. 2000. Ripening of Cheddar cheese with added attenuated adjunct cultures of lactobacilli. J. Dairy Sci. 83:1684-1691.

Michaelidou, A., M. C. Katsiari, E. Kondyli, L. P. Voutsinas, and E. Alichanidis. 2003. Effect of a commercial adjunct culture on proteolysis in low-fat Feta-type cheese. Int. Dairy J. 13:179-189.

Milanovic, S., M. Kalab, and M. Caric. 1998. Structure of Kaskaval curd manufactured from milk or UF retentate using enzymes of various origin. Lebenson. Wiss. Technol. 31:377-386.

Morea, M., A. Matarante, R. Di Cagno, F. Baruzzi, and F. Minervini. 2007. Contribution of autochthonous non-starter lactobacilli to proteolysis in Caciocavallo Pugliese cheese. Int. Dairy J. 17:525534.

Ottogalli, G. 2001. Atlante dei Formaggi. Hoepli Editore, Milan, Italy.

Piraino, P., T. Zotta, A. Ricciardi, and E. Parente. 2005. Discrimination of commercial Caciocavallo cheeses on the basis of the diversity of lactic microflora and primary proteolysis. Int. Dairy J. 15:1138-1149.

Resmini, P., L. Pellegrino, J. Hogenboom, and M. Bertuccioli. 1988 Atti Giornata di Studio. Consorzio del Formaggio Parmigiano Reggiano, Reggio Emilia, Italy.

Rossetti, L., and G. Giraffa. 2005. Rapid identification of dairy lactic acid bacteria by M13-generated, RAPD-PCR fingerprint databases. J. Microbiol. Methods 63:135-144.

SAS Institute. 1985. User's Guide: Statistics. Version 5 ed. SAS Institute Inc., Cary, NC.

Upadhyay, V. K., T. Huppertz, A. L. Kelly, and P. L. H. McSweeney. 2007. Use of high pressure treatment to attenuate starter bacteria for use as adjuncts for Cheddar cheese manufacture. Innov. Food Sci. Emerg. Technol. 8:485-492.

Upadhyay, V. K., and P. L. H. McSweeney. 2003. Acceleration of cheese ripening. Pages 419-447 in Dairy Processing: Improving Quality. G. Smit, ed. Woodhead Publishing, Cambridge, UK.

Zwietering, M. H., I. Jongeberger, F. M. Roumbouts, and K. van't Riet. 1990. Modeling of bacterial growth curve. Appl. Environ. Microbiol. 56:1875-1881. 